\title{
STATUS OF AIR POLLUTION OVER THE LAST THREE DECADES IN THIMPHU CITY, BHUTAN
}

\author{
Govinda Prasad Sharma ${ }^{1,2}$, Ramesh Prasad Sapkota ${ }^{2}$, Enna Mool $^{2}$, Tulsi Gurung ${ }^{3}$, Rejina Maskey Byanju ${ }^{2 *}$ \\ ${ }^{I}$ Royal Thimphu College, Royal University of Bhutan, Thimphu, Bhutan \\ ${ }^{2}$ Central Department of Environmental Science, IOST, Tribhuvan University, Nepal \\ ${ }^{3}$ College of Natural Resources, Royal University of Bhutan, Punakha, Bhutan \\ "Corresponding author: rmaskey@cdes.edu.np
}

(Received: February 05, 2021; Revised: May 30, 2021; Accepted: June 04, 2021)

\begin{abstract}
With an increasing human population and vehicles, air pollution in Thimphu City is growing and causing a risk to human health, properties, and ecosystems. The population of Thimphu was 79,185 in 2005 but in 2017 it surged up to 114,551. An increase in the human population has also led to the rising demands for vehicles and thus increased the vehicular emissions in the area. Additionally, the use of traditional fuels, burning of waste and agriculture residues, forest fire, and transboundary pollutants are other sources resulting in poor air quality in Thimphu City. Air pollution data from journal articles, government documents, reports from national and international organizations, and books were reviewed. Concentrations of $\mathrm{PM}_{10}, \mathrm{PM}_{2.5}, \mathrm{SO}_{2}, \mathrm{NO}_{2}$ were increasing over the decades. The annual average $\mathrm{PM}_{10}$ recorded in Thimphu was $28 \mu \mathrm{g} / \mathrm{m}^{3}$ in 2005, $47 \mu \mathrm{g} / \mathrm{m}^{3}$ in $2010,43 \mu \mathrm{g} / \mathrm{m}^{3}$ in 2014 , and $42 \mu \mathrm{g} / \mathrm{m}^{3}$ in 2015 . Winter months were found to have higher $\mathrm{PM}_{10}$ and $\mathrm{PM}_{2.5}$ concentrations. The 24-hourly average concentrations of $\mathrm{SO}_{2}$ ranged from 0.0 to $6.9 \mu \mathrm{g} / \mathrm{m}^{3}$ and $\mathrm{NO}_{2} 8.2-26.6 \mu \mathrm{g} / \mathrm{m}^{3}$. There is a need for comprehensive studies to identify spatial and temporal variations in the ambient concentration of the pollutants in the area. Strict enforcement of the legal frameworks is essential for the mitigation of air pollution in Thimphu City.
\end{abstract}

Keywords: Air pollution, Pollutants, Thimphu, Urban population, Vehicular emission

\section{INTRODUCTION}

Thimphu, the capital of Bhutan, houses all the ministries, and a large proportion of the employed population in government services (MoWHS, 2008). With the inflow of population and the growing number of vehicles, air pollution in Thimphu has been a major growing concern. NEC (2016) noted the rise of gaseous air pollutants, such as $\mathrm{CO}, \mathrm{NO}_{\mathrm{x}}, \mathrm{SO}_{2}, \mathrm{PM}_{2.5}, \mathrm{PM}_{10}$, total suspended particles (TSP), lead, and aromatic compounds in the atmosphere.

The major sources of air pollutants are transportation, resuspension, firewood burning for cooking and heating, smoke from a forest fire, and the burning of agricultural debris. The other sources of air pollution are smoke from open fires for road construction and outdoor recreations, emission from industries, and transboundary air pollution (NEC, 2010). Significant amounts of air pollutants emitted from outside the country are also contributing to poor air quality in Thimphu City (ICIMOD, 2019).

Bhutan is a party to the United Nations Framework Convention on Climate Change (UNFCCC), and therefore catches a good move as the greenhouse gases (GHG) inventory system (NEC, 2000). The country is in a highly vulnerable position to climate change and faces a range of threats. NEC (2000) determined 6 areas most vulnerable to the impacts of climate change in Bhutan, and these comprised of agriculture, forests and biodiversity, water resources, glaciers, human health, and land surfaces. The vulnerabilities to different sectors of the country from climate change are shown in the National Adaptation Programs of Action and the Second National Communication to the UNFCCC (NEC, 2005, 2011) Erratic and localized rainfall is more common and has become the cause of flash floods and landslides. Glaciers melting are affecting water availability and creating a risk of floods in the downstream areas. Some streams are drying up causing water scarcity in some parts of Bhutan (NEC, 2016).

Wangchuk (2011) revealed that Thimphu had one of the fastest annual human growth rates in the world, and it is one of the 15 cities, critical to the impact of climate change. Johnson (2020) argued that private cars in Thimphu are major contributors to air pollution. Bhutan's emissions from vehicles will rise if Bhutanese continue to buy vehicles at the current pace. If left unchecked, it could intensify respiratory diseases, lead to premature deaths, and put Bhutan's wish of remaining carbon neutral in peril (Johnson, 2020).

Hence, there is a need for scientific quantitative air quality study and enforcement of rules, laws, and regulations for effective management and mitigation of air pollution in Thimphu City. This narrative review aimed to discuss the status of air pollution in Thimphu City, and to examine various sources influencing the rise of poor air quality. The existing initiatives for mitigating air pollution problems were also assessed. 


\section{MATERIALS AND METHODS}

This study is based on the narrative review of published documents on air pollution from journal articles, government documents, reports from national and international organizations, books, and relevant websites. The data and information were collected from notable organizations' publications such as of the National Environment Commission (NEC-Bhutan), National Statistical Bureau (NSB-Bhutan), UNEP, ADB, UNDP, WHO. The contents of this review paper include the human population data of Thimphu City, sources and level of air pollutants, available pollutant levels status of $\mathrm{CO}, \mathrm{PM}_{10}, \mathrm{PM}_{2.5}, \mathrm{NO}_{\mathrm{X}}, \mathrm{SO}_{2}$, and other pollutants, impacts of air pollution, and major organizations that work with NEC for monitoring air pollution in Bhutan.

\section{RESULTS AND DISCUSSION}

\section{Population dynamics}

According to CSO (1994), until 1994, Thimphu had a population of about 35,000 that accounted for only $14.5 \%$ of the population. The development of educational institutes, infrastructures, and availability of health services emphasized the advantages of urban areas and attracted more students, job seekers, business personnel, entrepreneurs, and also the general public in Thimphu. The transportation infrastructures also proved a major force for urban development, thus increasing accessibility to citizens from across the country (NEC, 2002). Further, the population increased over the years in Thimphu because of the diminishing employment, educational, and social prospects in rural areas (CSO, 1994). Due to ruralurban migration, Thimphu's urban population has put increasing pressure on the natural resources of urban and peri-urban areas (NEC, 2000). Until 2006, the urban population was increasing annually at a rate of $6.7 \%$ in Bhutan (ADB, 2006).

Fig. 1 shows an increase of 79,551 people in Thimphu, a significant upsurge from 1994 to 2017. The rise of the human population from 2000 to 2005 had almost doubled, and from 2005 to 2010 , the increase was $31.6 \%$ (NSB, 2019a). Due to this increase, almost all the wetlands have been converted into housing colonies, shopping complexes, sports, and recreational centers affecting the abundances of urban flora and fauna. For instance, wood snipes once common in Thimphu have not been observed since 1999 (Wangchuk, 2011). The literacy level of people living in Thimphu was $71.4 \%$ in 2017 and the majority opts for buying personal vehicles (NSB, 2017).

\section{Transportation sector}

NSB (2015) reported that motor vehicles or surface transport, introduced in 1962, continued to be the main means of transportation in Bhutan. The privatization of the passenger transport services began in 1985. From
1991, twenty one operators managed a fleet of more than 100 buses in the country. The ADB (2006) found increased vehicular movement during peak hours mainly at 8-9 AM and 4-5 PM.

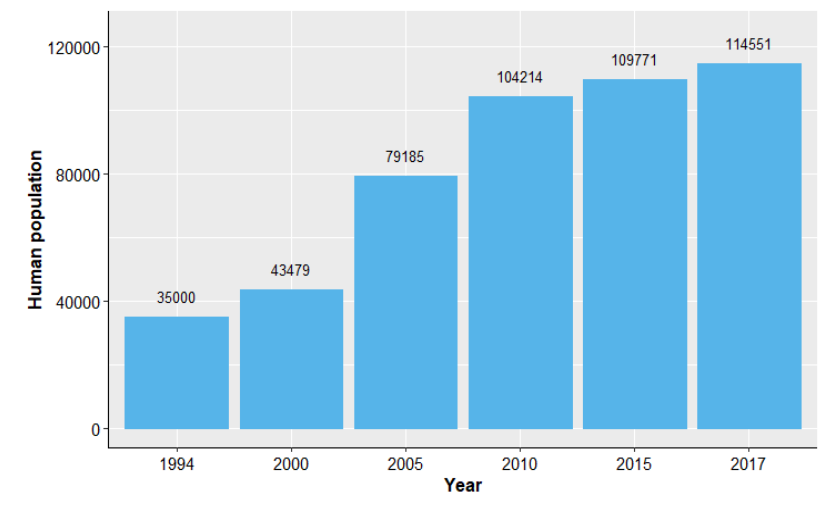

Fig. 1. Thimphu human population trend (Data sources: CSO, 1994; NSB, 2012; NSB, 2018; RGoB, 2005; TT, 2006; UNDP, 2018)

Fig. 2 demonstrates a large increase in vehicles from 8712 to 100544 in Bhutan from 1990 to 2018 (Dorji, 2019) and the growth trend in the increase in vehicles is higher compared to early 1990s (CSO, 1999). There were 4491 vehicles in 1990 and rose to 51830 in 2018 in Thimphu City, an addition of 47339 vehicles in the eighteen years. In terms of vehicle distribution, $51.6 \%$ were recorded under the Thimphu region (MoWHS, 2015).

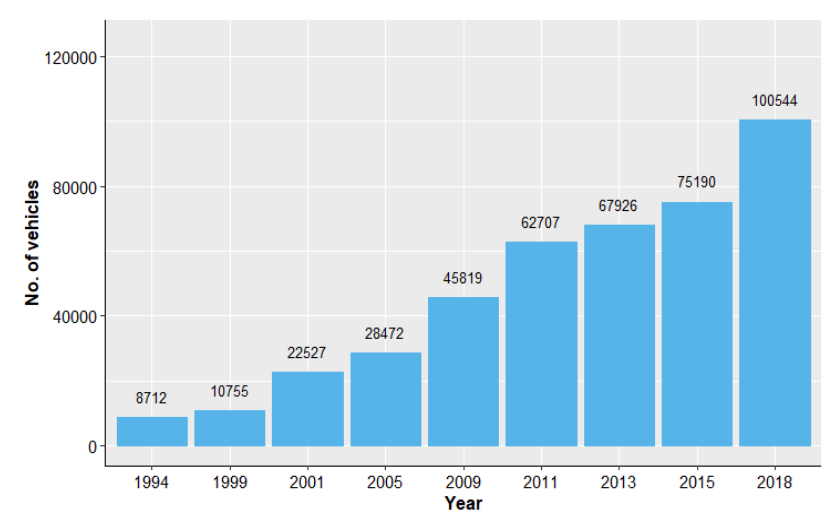

Fig. 2. Vehicle growth trend from 1994 to 2018 in Bhutan (Data source: Dorji, 2019; MoIC, 2020)

In Thimphu, the major sources of air pollutants are cars, buses, heavy-duty vehicles, and medium-sized trucks those use liquid fuels for their operation. According to RSTA (2015), heavy-duty vehicles were responsible for the emission of about 70-90\% of local pollutants, and more than half of the GHGs emissions in the year 2014 2015 in the country. The lower price of diesel fuel encouraged to buy a larger number of diesel vehicles (NEC, 2002). During winter, the diesel vehicles need to heat the engine and are required to keep in start mode to a 
minimum of 15 minutes (NEC, 2002). In this process, higher emissions of $\mathrm{CO}, \mathrm{NO}_{2}$, hydrocarbons, and particulate matter into the atmosphere are likely. Hydrocarbons emissions are more from age-old cars (UNEP, 2001). It was noted that the diesel with high sulfur $(0.25 \%)$ and the vehicles that were not fitted with high-altitude compensators emit more soot (NEC, 2002). In the National Environment Protection Act 2007, there is a provision stating the "Polluter Pays Principle" (NEC, 2007); however, it needs to be implemented effectively.

Bhutan imports a variety of fuels such as fossil fuel, kerosene, aviation fuel, furnace oil, liquefied petroleum gas (LPG), etc. The import of diesel accounts for 40-50\% of the total energy for the transport sector (NSB, 2018). It is followed by coal for the industry sector (26-30\%) and petrol (10-12\%) for the transport sector. Vehicle testing performance is also not satisfactory. Vehicle emission testing in Thimphu in 2003 showed that $16 \%$ of 1,385 diesel vehicles tested failed the established Bhutan Motor Vehicle Emission Standards (RSTA, 2004). Similarly, 5 $\%$ of 1,342 petrol vehicles failed the Emission Standards for Petrol. Vehicle emissions increased with the poor quality of fuel and most vehicles were not fitted with appropriate high-altitude compensators (RSTA, 2004). Low fuel quality, poor vehicle maintenance and facilities, and geographical factors such as high altitude and narrow valleys particularly magnify the problem of vehicular pollution in Thimphu (Wangdi, 2013). India introduced measures to implement standards equivalent to Euro 4 by 2018 and Euro 6 by 2021. Since Bhutan buys vehicles from India, there is a need to upgrade the emission standards of vehicles (ADB, 2019). IRENA (2019) claimed that scaling up renewable energy resources would reduce air pollutants emissions.

Further, it will create jobs in the country and help reduce dependence on fossil fuel imports (IRENA, 2019). Air pollution in Bhutan, is deteriorating and the problem may become more critical. The State of Environment 2016 reported that the concentration of $\mathrm{PM}_{10}$ particles measured in the capital city Thimphu had already exceeded European Union thresholds, and more than doubled the limits recommended by WHO (NEC, 2016). The number of vehicles purchased has not decreased as people always opt for private vehicles over public transportation despite rising air pollution and other environmental impacts. Moreover, unpaved dusty roads (UNEP, 2002) and the heating of bitumen along with the road construction sites also contribute to air pollution. Heating of bitumen emits soot, particles, and other polycyclic aromatic hydrocarbons (PAH) (ADB, 2006; NSB, 2019b). Strict enforcement of the existing legal frameworks and amendments are essential for the mitigation of air pollution. However, such practices are in a primitive stage in developing countries like Nepal (Shakya et al., 2019; Das et al., 2018).

\section{Industrial air pollution}

With supporting infrastructures such as water, energy supplies, sanitation, and transport, Thimphu has a combination of residential, commercial, industrial, and government buildings (MoWHS, 2008). There were 742 industries in 1990 but rose to 43094 in 1996 in Bhutan (MoP, 1996). In the Bhutanese context, the industries cover the whole array of activities comprising of manufacturing, mining, wholesale, retail trade, and other service. Small-scale industries such as wood factories, incense factories, and vehicle workshops available in limited numbers in the past have increased in recent years. ADB (2004) reported that these small-scale plants are not efficient and lack pollution control systems.

The major air pollutants emitted from the industries are $\mathrm{CO}_{2}, \mathrm{CO}, \mathrm{SO}_{2}, \mathrm{NO}_{2}$, and particulate matter. ADB (2004) found that most of the industries have low emission stack heights and are contributing to air pollution. The inventory on the concentration of particulate matters observed in and around industries is lacking. All industries in Bhutan, with the licenses issued by the Ministry of Trade and Industry, come under the purview of the Environmental Assessment Act of 2000 of Bhutan (ADB, 2006; NEC, 2007, 2000). From 2000 onwards, the execution of the Act has regulated old and new industries' emissions. The number of industries is increasing yearly in Thimphu and most are small-scale and service industries. In Thimphu, the vehicle workshops were located haphazardly in the earlier days, but now they are consolidated in one place (Olaronchu) for reducing land, air, and water pollution in the cities (NEC, 2007).

\section{Indoor air pollution}

In Bhutan, the high-energy demand is fulfilled from fuel wood, although its use has dropped from $91 \%$ to $87 \%$ during 2005-2014 (IRENA, 2019). The uses of energy are mainly for heating, cooking, and lighting in residential, industrial, and commercial sectors. Fuel wood for cooking has been replaced by LPG, electricity and biogas, and for space heating electricity has replaced fuel wood. The institutional and commercial sectors are still dominated by biomass use (IRENA, 2019). At present, the various sources of energy in Bhutan are petrol and petroleum products $(5 \%)$, biomass $(36 \%)$, electricity (28\%), coal $(15 \%)$, and diesel $(16 \%)$. Given the rising electricity demand, Bhutan is exploring other clean and renewable energy sources such as solar, wind to create a sustainable energy system (IRENA, 2019).

UNEP (2001) reported that $25,954 \mathrm{~m}^{3}$ of firewood was used in Thimphu yearly for cooking and heating, thus causing air pollution, mainly during winter months (NEC, 2004). MoWHS (2008) reflected that as per the Population and Housing Census of Bhutan 2005, $4 \%$ of the city household's population use kerosene, $2 \%$ fuel 
wood, and $45 \%$ used LPG for cooking purposes. Wangchuk (2016) in his study of Eastern Bhutan villages found that nearly $70 \%$ of the population used biomass fuels for cooking and space heating and indoor air quality problem was anticipated. Therefore, scientific air quality investigations are necessary for Bhutan (Wangchuk, 2016). Household air pollution resulting from the use of firewood for cooking also influences outdoor air quality in rural areas exceeding the WHO guidelines Wangchuk (2017). Cultural practices such as the use of burning incense sticks, lighting of butter lamps, burning of pine leaves during rituals also contribute to indoor air pollution in Thimphu Valley (NEC, 2016).

\section{Air pollution from waste generation}

Air pollutants are also emitted from the burning of wastes. Solid waste management has always been a problem in Thimphu City, and this condition has deteriorated with the growing population (RGoB, 2000; NEC, 2000). The Thimphu City Corporation had developed a landfill site for the safe disposal of wastes. Solid waste generation and disposal contribute to air pollution (NEC, 2008). Breakdown of solid waste leads to unpleasant odors and emits methane and $\mathrm{CO}_{2}$, particularly when not treated and disposed of haphazardly. It was noted that high levels of raw sewage and domestic wastes were flow in the storm drains and mix into the river, Thimchhu (MoWHS, 2008). According to MoWHS (2018), the waste-management has been a difficult assignment to deal with. It reported that municipal solid waste and medical waste generation was 8 MT/year in 1994 but rose to $36.5 \mathrm{MT} /$ year in 2007 (MoWHS, 2008). There was a lack of human resources with Thimphu City Corporation in the earlier days (UNDP, 2012). The garbage collection in 2011 was 45 metric tons/day and in 2015 it reduced to 25-30 metric tons/day.

The waste segregation into organic and inorganic wastes collection was started only in 2013 by the Thimphu City Corporation (MoWHS, 2015). The total waste generated in Thimphu City is about $0.35 \mathrm{~kg} /$ capita/day. Based on a survey, the composition of solid waste was mostly organic (58\%), followed by paper $(9.2 \%)$, plastics (13\%), and others $(19.8 \%)$ in Thimphu (NSB, 2019b). For the management of solid waste, Thimphu City outsources private companies such as Greener Way, Royal Society for Protection of Nature, Clean Bhutan, and Green Road to manage the wastes (Shrestha, 2018).

Air pollution has also emerged in urban centers like Thimphu due to the burning of rubbish in the absence of waste disposal systems. RSPN (2015) reported that waste problems arise from the change in the resource consumption pattern of the urban inhabitants, lack of awareness, and lack of responsibilities among the citizens. They further reported that the absence of coordination among institutions for waste management, lack of strong legal framework and implementation mechanisms, and rise in rural-urban migration of people contributed to more waste production in Thimphu (RSPN, 2015). The prevention, reduction, and management of wastes were encouraged and initiated for reusing, reducing, and recycling (NSB, 2019b). With such practices, it is expected that air pollution levels may decline from wastes as compared to earlier years in Thimphu City.

\section{Pollutants from agricultural activities}

Agriculture provides subsistence needs of about $58 \%$ of the population and generates about $17 \%$ of the GDP of Bhutan (UNDP, 2019). In 1998, Thimphu town was only $8.0 \mathrm{~km}^{2}$, but now it is expanding across the valley (MoWHS, 2018). It shows that agricultural land and agricultural activities have decreased in Thimphu Valley. In the earlier days, the residents of Thimphu used to burn kitchen garden wastes during the dry season which also contribute to the air pollution (UNEP, 2002). No data exists on how much air pollution contributed through agricultural residue burning and activities. Nonetheless, the government initiated programs such as the introduction of smokeless stoves for heating, tax incentives for importing room heaters that consume renewable energy, and the development of standards to improve and monitor air quality in Thimphu Valley (ADB, 2006).

\section{Transboundary air pollution}

Bhutan started implementing programs of the Malé Declaration in 2002. A monitoring station situated in Bhur in Southern Bhutan was initiated to collect data each month for the parameters $\mathrm{PM}_{10}, \mathrm{NOx}, \mathrm{SO}_{2}$, and wet and dry deposition (UNEP, 2013). Abas et al. (2019) stated that the coal-based power producers particularly China and India are accelerating smog formation in the atmosphere. They reported that the average $\mathrm{PM}_{10}$ concentration of India and China were 109 and $98 \mu \mathrm{g} / \mathrm{m}^{3}$, respectively, but range in some of their cities are between 500 and $900 \mu \mathrm{g} / \mathrm{m}^{3}$. On the other hand, average $\mathrm{PM}_{10}$ levels of Pakistan, Bangladesh, Nepal, Myanmar, Sri Lanka, and Bhutan were reported to be 198, 120, 106, 96, 77, and $18 \mu \mathrm{g} / \mathrm{m}^{3}$, respectively (Abas et al., 2019). Air pollution created in one country affects the neighboring country as well. Smog and atmospheric brown clouds (ABC) affect millions of people every year not only in China and India but also in the neighboring countries (Abas et al., 2019). As such, there is a need to tackle the issues of transboundary air pollution through utmost coordination and affably in the region.

Air pollution has increased over the years in many cities in the Hindu Kush Himalayas (HKH) and across the IndoGangetic Plain (WHO, 2016). In the HKH, higher concentrations of regional haze and winter fog occurrences as well as increased $\mathrm{O}_{3}$ in southern $\mathrm{HKH}$ 
foothills were noted during the dry season (Saikawa et al., 2019). During the winter months, the foggy pollution level along the southern belt of Bhutan was visible (NEC, 2016). Further, research also indicated that the pollutionladen clouds could also badly affect agricultural productivity, setbacks tourism, and affect the lives of millions of people (Saikawa et al., 2019).

\section{Forest fire}

Chhetri (1994) found that forest fire was one of the sources of air pollution in Bhutan, but there is little documented research and literature on the effects on the ecosystems. Forest fire is perceived as a big threat to Bhutan conservation efforts. The effects of forest fires are highly sensitive in the mountainous ecosystem as it needs a long time to revive and restore completely from such fire incidents (Chhetri, 1994). These fires caused by both anthropogenic and natural causes are affecting the availability of forest resources (Bhujel et al., 2018). The burning of agriculture residues nearby forests, enabling the growth of seedlings and saplings of plant species in summer by burning dry grass, negligence of villagers, campers, and travelers are some anthropogenic causes (DOF, 2005). The wind carries forest fire emissions from other nearby districts to Thimphu (NEC, 2010).

According to the DFPS (2016), in the year 2016, seventy two fire incidences damaged 8521.85 ha of forest areas. The districts with the higher forest fire incidences were Thimphu, Mongar, Wangduephodrang, and Trashigang (DFPS, 2016; NEC, 2016). The number of incidences of forest fire has been increasing despite various fire management and advocacy programs carried out by the Department of Forests under the Ministry of Agriculture and Forests (FRMD, 2018). Agee (1993) argued that about $90 \%$ of fire emissions consist of carbon dioxide and water vapor. The portion of the carbon in smoke is particulate matter, $\mathrm{CO}$ (pollutant), and volatile organic matter (Agee, 1993).

\section{Status of air pollution}

Ambient air quality monitoring has been carried by NEC in Thimphu and Phuentsholing intermittently since 2002. In earlier days, the quality of air was pristine, except during the dry winter seasons. The values were higher for winter months due to higher concentrations of particulate matter, constant winter high-pressure, and temperature inversions (NEC, 2004). TSP readings of 150-250 $\mu \mathrm{g} / \mathrm{m}^{3}$ (24-hour average) in 2004 were recorded during January and February in Thimphu (NEC, 2004). In 2004, the $\mathrm{NO}_{2}$ and $\mathrm{CO}$ concentrations recorded were $10.49 \mu \mathrm{g} / \mathrm{m}^{3}$ and $7.14 \mathrm{mg} / \mathrm{m}^{3}$, respectively (ADB, 2004; NEC, 2004). The NEC recorded ambient air quality data for 180 sampling days in the premises of Tashichhodzong between June 2004 and May 200 and the particulate matter concentrations were observed higher during winter (NEC,
2008). Annual average $\mathrm{PM}_{10}$ concentrations in Thimphu recorded at NEC station were $28 \mu \mathrm{g} / \mathrm{m} 3$ in $2005,47 \mu \mathrm{g} /$ $\mathrm{m}^{3}$ in $2010,43 \mu \mathrm{g} / \mathrm{m}^{3}$ in 2014 , and $42 \mu \mathrm{g} / \mathrm{m}^{3}$ in 2015 (NEC, 2016). An increasing trend in $\mathrm{PM}_{10}$ concentrations from 2005 to 2015 was shown in Thimphu (ADB, 2019). Namgyel (2008) presented, 24 hourly average values, for TSP within the range of $100-504 \mu \mathrm{g} / \mathrm{m}^{3}, \mathrm{PM}_{10} 49-389$ $\mu \mathrm{g} / \mathrm{m}^{3}, \mathrm{SO}_{2} 0-6.9 \mu \mathrm{g} / \mathrm{m}^{3}, \mathrm{NO}_{2} 8.2-26.6 \mu \mathrm{g} / \mathrm{m}^{3}$. The eight hourly average values for CO were $200-800 \mu \mathrm{g} / \mathrm{m}^{3}$ (NEC, 2010).

Fig. 3 shows that the $\mathrm{PM}_{10}$ concentrations are more from October to May, with the average of $35.02 \mu \mathrm{g} / \mathrm{m}^{3}$. However, in the summer months (June to September), the $\mathrm{PM}_{10}$ and $\mathrm{PM}_{2.5}$ concentrations are low. For instance, $\mathrm{PM}_{2.5}$ concentrations are low from July to September and remain $<10 \mu \mathrm{g} / \mathrm{m}^{3}$. The average $\mathrm{PM}_{2.5}$ value is 24.73 $\mu \mathrm{g} / \mathrm{m}^{3}$ and the level concentrations are high from October to June. The rise and fall of $\mathrm{PM}_{10}$ and $\mathrm{PM}_{2.5}$ concentrations over the year are similar in Thimphu city. The $\mathrm{PM}_{2.5}$ particles are more concerned than the $\mathrm{PM}_{10}$ because of their small size and this allows smaller particles to travel deeper into the human cardiopulmonary system. Annual mean concentrations of $\mathrm{PM}_{2.5}$ and $\mathrm{PM}_{10}$ should not exceed $10 \mu \mathrm{g} / \mathrm{m}^{3}$ and $20 \mu \mathrm{g} / \mathrm{m}^{3}$, respectively, as per the WHO air quality guidelines (WHO, 2006).

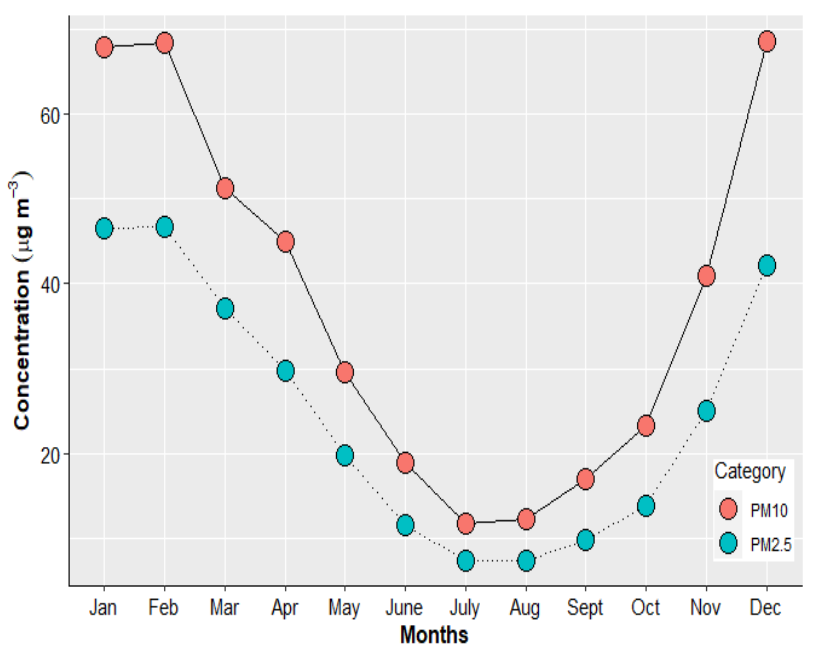

Fig. 3. Average concentrations of $\mathbf{P M}_{10}$ and $P M_{2.5}$ in years of 2016, $2017 \& 2018$ (Data source: NSB, 2019a)

Atmospheric sources of PAH are incomplete combustion of coal, oil, biomass, motor and aviation fuels. The concentration of PAH is also an indicator of the amount of fuel consumed in a particular region (NEC, 2010). World Bank (2014) indicated the need of strengthening the Bhutan statistical system with a focus on human resources development and data coordination. There is an immediate need to install a network of automated air quality monitoring station to collect the level of all pollutants in Thimphu. Further, measures such as eco- 
driving, regular maintenance of vehicles, awareness, and capacity-building programs are required.

\section{Impacts on human health by air pollution}

In Bhutan, the mortality caused by cardiovascular disease was $18 \%$ (highest of all diseases) and respiratory diseases were $6.5 \%$, until $2000(\mathrm{MoH}, 2015)$. In 2016, the number of deaths from respiratory disease was $9.0 \%$, an increase of $2.5 \%$ compared to the year 2000 (WHO, 2018). The trend of respiratory disease is the top-ten causes of mortality in Bhutan, which occupied the first position in 2010, second in 2015, and third in 2019 ( $\mathrm{MoH}, 2020)$. There is an increasing trend of respiratory diseases and it is necessary to curtail the air pollution in Bhutan. UNEP (2002) noted an increase in the incidence of acute respiratory diseases, cough and colds, bronchitis, and asthma in Bhutan. It was reported that acute respiratory tract diseases increased from $10.1 \%$ in 1990 to $14.0 \%$ in 1998, whereas other respiratory diseases have increased from $2.5 \%$ in 1990 to $6.8 \%$ in 1998 (UNEP, 2002).

Other factors such as unpredictable climatic conditions, health care and nutritional negligence, infection, smoking, and indoor air pollution can also contribute to respiratory diseases and related deaths in the country (NEC, 2008). ADB (2006) reported a growing concern about the health and environmental impacts of air pollution due to rapid urbanization and transport infrastructure development in Thimphu. The benzene produced during the combustion of wood and fossil fuels is a carcinogen, and toluene and xylene are also suspected carcinogens produced by petrol vehicles (NEC, 2010). Johnson (2020) found that air pollution in Thimphu has doubled between 2007 and 2018, and could aggravate asthma and lead to premature deaths from heart disease. It is imperative to find the correlation between air pollution and the occurrence of respiratory diseases and related deaths in Thimphu City and also in Bhutan.

\section{Support to combat Air Pollution}

The NEC serves as a mentor to the Royal Government of Bhutan concerning the environment (NEC, 1998). For the developmental process in Bhutan, environmental conservation is prioritized and integrated. The NEC has formulated "The Middle Path", as the guiding principle of development (ADB, 2006). The NEC publishes periodic State of Environment (SOE) reports providing environmental information to the citizens covering pressure, state, trend, and responses of Bhutan's environment (NEC, 2016). NEC as the coordinating agency works closely with other line ministries and departments to tackle the air pollution problem. Various national and international organizations are working with NEC for monitoring air pollution in Bhutan. The Ministry of Trade and Industry works for industrial air pollution, Ministry of Health and Education study health problems related to air pollution, Central Statistical Organization works on data and inventories, Meteorology Division looks after climate change and weather, and City Corporations and Road Safety and Transport Authority (RSTA) work on urban air pollution management. The NEC in association with the RSTA, Royal Bhutan Police, and vehicle importers works modalities of implementation and enforcement of the enhanced standards (NEC, 2008).

Further, Bhutan participates actively in the South Asian Association of Regional Cooperation (SAARC), United Nations Environment Program (UNEP), World Bank, Asian Development Bank, Economic, and Social Commission for Asia and the Pacific (ESCAP), and the International Center for Integrated Mountain Development (ICIMOD) (NEC, 2000). Bhutan is working closely with ICIMOD on different aspects such as the purchase of air pollution instruments and apparatus, support in installing air-monitoring stations, and training the technicians (ICIMOD, 2019).UNDP is working with Bhutan on a project called "Bhutan Sustainable Lowemission Urban Transport Systems" from 2019 through 2023. The project aims to accelerate the low-carbon transition in Bhutan's urban transport sector by promoting low emission vehicles, such as electric cars. It is anticipated that the transformation to clean energy and zero-carbon development would facilitate low-carbon transport modes to improve air quality in urban zones and mitigate climate change (UNDP, 2018). There are numerous national, regional, and global partners working closely with NEC-Bhutan to improve air quality in urban cities like Thimphu.

\section{CONCLUSION}

Ample evidences show that there is a rise in air pollution in Thimphu City in recent years. $\mathrm{PM}_{10}$ and $\mathrm{PM}_{2.5}$ concentrations are higher during the winter months. The growth in human population, vehicle numbers and industries, use of traditional fuels, burning of waste and agriculture residues, forest fire, and transboundary air pollution are the sources for increasing concentrations of air pollutants. However, the status and contribution of these sources have not been quantified, and very less explored. Managing the air pollution situation requires comprehensive empirical researches. Without field-based monitoring, measurement, and quantification, actual air quality-related issues and the resulting health disorders cannot be identified. Similarly, strict implementation of the existing policies is essential for reducing the increasing air pollution level of the country.

\section{ACKNOWLEDGEMENT}

The authors would like to express sincere gratitude to the Central Department of Environmental Science, Tribhuvan University for providing support to assess information archives and required logistics. 


\section{CONFLICT OF INTEREST}

There is no conflict of interest relating to the material presented in the article. The opinions and/or conclusions expressed are exclusively those of the authors.

\section{REFERENCES}

Abas, N., Saleem, M. S., Kalair, E., \& Khan, N. (2019). Cooperative control of regional transboundary air pollutants. Environmental Systems Research, 8, 10. https://doi.org/10.1186/s40068-019-0138-0

ADB. (2004). Bhutan country environmental analysis. RSC No.C40700-BHU; PP 28-29, Asian Development Bank, New Zealand: Maunsell Limited.

ADB. (2006). Country synthesis report on urban air quality management Bhutan. Asian Development Bank and the Clean Air Initiative for Asian Cities (CAI-Asia) Center.

ADB. (2019). Bhutan vehicle emission reduction road map and strategy, 2017-2025. Zheng, L., Gerpacio, R.V., Gruetter, J., Amar, L.Y. (Eds), Asian Development Bank Briefs, No.110. (Accessed on 23 Nov. 2020 from: https://www.adb.org/sites/default/files/publication/5 13931/adb-brief-110-bhutanvehicle-emissionreduction-strategy.pdf)

Agee, J. K. (1993). Fire ecology of Pacific Northwest forests. Washington, DC, USA: Island Press, p. 493.

Bhujel, K. B., Byanju, R. M., \& Gautam, A. P., (2018). Wildfire dynamics and its effects on the forest resources and public property in Nepal. Journal of Institute of Science and Technology, 23, 61-68.

Chhetri, D.B. (1994). Seasonality of forest fires in Bhutan. In International Forest Fire News (IFFN) No. 10 (pp. 5-9), Ministry of Agriculture, Department of Forestry Royal Government of Bhutan Forest Protection Cell, Forest Research Division, TabaThimphu, Bhutan.

CSO. (1994). Statistical yearbook of Bhutan. Central Statistics Office, Royal Government of Bhutan, Printed by Planning Commission, Bhutan.

CSO. (1999). Statistical yearbook of Bhutan. Central Statistics Office, Royal Government of Bhutan. Printed by Planning Commission, Bhutan.

Das, B., Bhave, P. V., Puppala, S. P., \& Byanju, R. M. (2018). A global perspective of vehicular emission control policy and practices: an interface with Kathmandu Valley case, Nepal. Journal of Institute of Science and Technology, 23(1), 76-80.
DFPS. (2016). Forest facts \& figures 2016. Department of Forests and Park Service, Royal Government of Bhutan, Ministry of Agriculture and Forests (Accessed on 13 Oct. 2020 from http://www. dofps.gov.bt/wpcontent/uploads/2017/07/ForestBookletFina).

DoF. (2005). Data on forest covers. social forestry. Royal Government of Bhutan, Published by Department of Forest, Bhutan.

Dorji, S. (2019). Status of intelligent transport systems (ITS) developments and related challenges and issues in Bhutan. Expert Group Meeting and Regional Meeting on Intelligent Transport Systems (ITS) Songdo, 2-4 April 2019, Republic of Korea. (Accessed on 13 Oct. 2020 from: https://www.unescap.org/sites/default/files/Country \%20presentation\%20-\%20Bhutan.pdf)

FRMD. (2018). Forest facts \& figures 2018. Compiled by the National Forest Information \& GIS Section of Department of Forest and Park Services, Forest Resources Management Division, Thimphu Ministry of Agriculture and Forests.

ICIMOD. (2019). Atmospheric watch initiative activities. International Centre for Integrated Mountain Development. (Accessed on 16 Nov. 2020 from: https://www.icimod. org/ initiative/atmosphericwatch-activities)

IRENA. (2019). Renewables readiness assessment: Kingdom of Bhutan. International Renewable Energy Agency, Abu Dhabi.

Johnson, E. (2020). Road to electric vehicles in Bhutan is paved with hurdles. The Third Pole (Accessed on 15 Nov. 2020 from: https://www.eco-business.com/ news/road-to-electric-vehicles-in-bhutan-is-pavedwith-hurdles/).

MoH. (2015). The multi-sectoral action plan for the prevention and control of non-communicable diseases in Bhutan (2015-2020). Ministry of Health (Accessed on 5 Dec. 2020 from www.who.int/ncds/governance/policies/BhutanNCD-MAP-2015-2020.pdf).

MoH. (2020). Annual health bulletin. Ministry of Health, Thimphu, P. T. Printing \& Publishing House Thimphu.

MoIC. (2020). Annual Info-Comm and Transport Statistical Bulletin. Policy and Planning Division, Royal Government of Bhutan. Ministry of Information and Communications (Accessed from: https://www.moic.gov.bt/wpcontent/uploads/2020/02/2020-Annual-Info-Command-Transport-Statistical-Bulletin-2019.pdf). 
MoP. (1996). Eighth five-year plan (1997-2002). Bhutan, Ministry of Planning, Bhutan, Volume I.

MoWHS. (2008). Thimphu city development strategy. Ministry of Works and Human Settlement, Royal Government of Bhutan, City without Slums-Cities Alliance. www.mowhs.gov.bt

MoWHS. (2015). Annual information bulletin. Ministry of Works \& Human Settlement (Accessed on 26 Sept. 2020 from website www.mowhs.gov.bt).

MoWHS. (2018). Strategic environmental assessment for the Thimphu structure plan. Ministry of Works and Human Settlements, Royal Government of Bhutan, Thimphu.

Namgyel, T. (2008). National environmental standards: ambient air quality, industrial emissions, workplace air quality, noise levels. National Stakeholder Workshop for Bhutan under Malé Declaration Project Phase IV, Thimphu, National Environment Commission.

NEC. (1998). The middle path, a national environmental strategy of Bhutan. National Environment Commission, Royal Government of Bhutan: Keen Publishing (Thailand) Co. Ltd.

NEC. (2000). Under the United Nations framework convention on climate change. National Environment Commission, Royal Government of Bhutan: Kuensel Corporation.

NEC. (2002). Bhutan- The Road from Rio, National Assessment of Agenda 21 in Bhutan. National Environment Commission, Royal Government of Bhutan. Printed in Thai Graphic \& Print Co., Ltd., Thailand.

NEC. (2004). Brief report on the state of the environment (pp. 5-6). National Environment Commission, Royal Government of Bhutan.

NEC. (2005). Bhutan national adaptation programme of action (NAPA I). National Environment Commission, Royal Government of Bhutan, Bhutan.

NEC. (2007). National environment protection act 2007. National Environment Commission, Royal Government of Bhutan, Bhutan.

NEC. (2008). Bhutan environment outlook 2008. National Environment Commission, Royal Government of Bhutan, Bhutan.

NEC. (2010). Strategy for air quality assessment and management in Bhutan. National Environment Commission, Royal Government of Bhutan, Bhutan.

NEC. (2011). Second National Communication to the UNFCCC. National Environment Commission,
Royal Government of Bhutan, Bhutan. Accessed on 24 Dec. 2020 from http://unfccc.int/resource/docs /natc/snc_bhutan.pdf

NEC. (2016). Bhutan State of the environment report 2016. National Environment Commission, Royal Government of Bhutan, Bhutan.

NSB. (2012). Statistical yearbook of Bhutan 2012. National Statistics Bureau, Royal Government of Bhutan, Bhutan.

NSB. (2017). Statistical yearbook of Bhutan 2017. National Statistics Bureau, Royal Government of Bhutan, Bhutan.

NSB. (2018). Population \& housing census of Bhutan. National Statistics Bureau, Royal Government of Bhutan, Bhutan.

NSB. (2019a). Nation's waste on the scale. National Waste Inventory Survey (NWIS-2019), National Statistics Bureau, Royal Government of Bhutan, Bhutan.

NSB. (2019b). Statistical yearbook of Bhutan 2019. National Statistics Bureau, Royal Government of Bhutan, Bhutan.

RGoB. (2000). First greenhouse gas inventory, initial national communication. Coordinated by National Environment Commission, Royal Government of Bhutan, under the United Nations Framework Convention on Climate Change, Bhutan. Printed at Kuensel Corporation.

RGoB. (2005), Population \& housing census of Bhutan 2005. Royal Government of Bhutan. (Accessed on 26 Nov. 2020 from http://www.bhutancensus.gov.bt)

RSPN. (2015). Strategic plan for royal society for protection of nature 2016-2020. Royal Society for Protection of Nature. (Accessed on 27 Dec. 2020 from: http://www.rspnbhutan.org/ wpcontent/uploads/2018/07/The-Fourth-Strategic-Planof-RSPN-2016-2020.pdf)

RSTA. (2004). Registration form. Road Safety and Transport Authority, Royal Government of Bhutan, Bhutan.

RSTA. (2015). Annual report. Road Safety and Transport Authority, Royal Government of Bhutan, Bhutan.

Saikawa, E., Panday, A., Kang, S., Gautam, R., Zusman, E., Cong, Z., Somanathan, E., \& Adhikary, B. (2019). Air Pollution in the Hindu Kush Himalaya. In P. Wester, A. Mishra, A. Mukherji, A. Shrestha (Eds.), The Hindu Kush Himalaya assessment (pp. 339-387). Cham: Springer. https://link.springer.com/chapter/10.1007/978-3319-92288-1_10 
Shakya, S., Baral, S., Belbase, P., Siddique, M. N., Samoh, A. N., Das, B., Shrestha, P., \& Shakya, P. (2019). Determination and contamination assessment of heavy metals in street dust from different types of land-use in Kathmandu District, Nepal. Journal of Institute of Science and Technology, 24(1), 6-18.

Shrestha, S. (2018) Bhutan project scoping, waste management, project scoping-urban pathways 2018. Lah, O. (Ed), Wuppertal Institute.

TT. (2008). Solid waste master plan. Thimphu Thromde, Bhutan.

UNDP. (2012). Partnerships for effective municipal service delivery. Knowledge, Innovation and Capacity: Partnerships for Effective Municipal Service Delivery, United Nations Development Programme, Asia-Pacific Regional Centre, p. 2.

UNDP. (2018). Bhutan sustainable low-emission urban transport systems. Project Document for nationally implemented projects financed by the GEF Trust Funds, United Nations Development Programme. https://erc.undp.org/evaluation/documents/download $/ 18443$

UNDP. (2019). Bhutan pursues climate resilience with national adaptation plan. United Nations Development Programme, Bhutan. (Accessed on 26 Dec. 2020 from: https://www.bt.undp.org/content/bhutan/en/home/pre sscenter/pressreleases/2019/bhutan-pursues-climateresilience-with-national-adaptation-plan.html)

UNEP. (2001). State of the environment, Bhutan 2001. United Nations Environment Programme (in collaboration with SACEP, NORAD and NEC).

UNEP. (2002). Handbook on environmental legislations and institutions in Bhutan (pp. 52-53). Tshering, K. N. (Ed.), Under the UNEP/ SACEP/ NORAD Publication Series on Environmental Law and
Policy. Atmosphere, South Asia Co-operative Environment Programme (SACEP).

UNEP. (2013). Malé declaration 1998-2013: a synthesis, progress and opportunities. United Nations Environment Programme. Thailand, Bangkok.

Wangchuk, D. T. (2011). Bhutan's modern face. China and the world discuss the environment. https://chinadialogue.net/en/cities/4322-bhutan-smodern-face/

Wangchuk, T. (2016). Quantitative assessment of air quality in different indoor and outdoor environments in rural Bhutan (Doctoral thesis), Queensland University of Technology, Australia.

Wangchuk, T. (2017). Characterization of particle mass and number concentrations for a rural location in Eastern Bhutan. Bhutan Journal of Research \& Development, 6(2), 3-13.

Wangdi, D. (2013). Presentation on measurement of inland transport $\mathrm{CO}_{2}$ emission and mitigation policies.

https://www.unescap.org/sites/default/files/3.1.Bhuta n.pdf

WHO. (2006). WHO Air quality guidelines for particulate matter, ozone, nitrogen dioxide, and sulfur dioxide. Global update 2005, summary of risk assessment. WHO/SDE/PHE/OEH/06.02.

WHO. (2016). Ambient air pollution: a worldwide assessment of exposure and burden of disease. World Health Organization. (Accessed on 13 Sept. 2020 from

https://apps.who.int/iris/handle/10665/25014)

WHO. (2018). Non-communicable diseases (NCD). Country Profiles, Bhutan, World Health Organization.

World Bank. (2014). Bhutan: country snapshots. World Bank. 